\title{
Development of a franchise and rating in the formation of programs for the development of higher project education
}

\author{
Valery Vladimirovich Glushchenko \\ Professor of the project activity Center, Moscow Polytechnic University, Moscow, Russia
}

\begin{abstract}
The subject of the article is the development of franchises and ratings as information technologies used in the development of higher project education; the object of the article is higher project education in the conditions of the sixth technological order, the purpose of the work is to develop programs for the development and rating of project universities in the transition of the education system to a new (sixth) technological order; to achieve the goals, the following tasks are solved: system analysis of higher project education; development of methods for forming programs for the development of higher project education; development of franchise content for the development of higher project education; the scientific methods in the work are system and historical analysis, forecasting, synthesis, predictive analysis, expert methods, structural and parametric analysis; scientific novelty is determined by the development of the methodology for the formation of programs for the development of project higher education, the development of the theory (functions and roles) of the rating, the creation of a methodology for the development of the rating of project higher education.
\end{abstract}

Keywords: franchise, methodology, development, program, higher education, management, project, system, structure, rating, efficiency, university.

\section{INTRODUCTION}

The relevance of this article is determined by the need for the development of higher project education. The need for the transition to project-based higher education is determined by the following factors: the increasing spread of the project approach in the work of real economy organizations in the context of the transition to the sixth technological order; the development of clip thinking among students in the context of information technology; the need to adapt the higher education system to changing environmental conditions.

The purpose of the work is to develop programs for the development of higher project education in the transition of the education system to a new (sixth) technological order.

To achieve these goals, the following tasks are solved:

- System analysis of higher project education.

- Development of methods for the formation of programs for the development of higher project education.

- Development of franchise content for the development of higher project education.

- Formation of the rating of evaluation of project universities.

- Formation of a subsystem for managing the implementation of programs for the development of higher project education. The object of the article is higher project education in the conditions of the sixth technological order.

The subject of the article is the development of franchises and ratings as information technologies used in the development of higher project education.

\section{PROPOSED PROGRAMS}

At the beginning of the 21 st century, the franchise is a popular tool for business development [1]. One of the ways to develop the higher education system has become a project-based higher education. Therefore, they study the practice of implementing project education in universities [2]. Scientists develop the theoretical foundations of project education [3]. Project education has a high innovative potential [4]. Educational programs have their own characteristics in project-based higher education [5]. To improve the effectiveness of project education, management systems can be used [6]. There is a practice of developing development programs [6]. In the sixth technological order, there is an intensification of innovation processes. The main organizational form of innovation implementation is the implementation of projects [7].

The competition of universities in the global market of educational services is becoming more intense [8]. World university rankings allow us to assess the position of individual universities in the market of educational services 
[9]. One of the ways to assess the status of the university is the formation of ratings of the sites of these universities [10]. The project method in higher education is further developed [11]. The development of the scientific theory of the project approach in the work of organizations of the real economy is carried out [12]. The analysis of the features of project-based higher education has shown the existence of such features. This gives grounds for the development of a separate rating of project universities [13]. At the same time, the rating of project universities can be considered as a tool for the development of the segments of higher project education [14].

Method. Under the development of a program for the development of project-based higher education, we will understand the establishment of the main activities. These activities should lead to the development of the higher project education segment in the higher education system. We will assume that the activities of the program are carried out on the basis of drawing up plans. Coordination of the time of implementation of measures is carried out when developing plans [6].

The franchise and rating can be considered as information technologies in the development programs of higher project education. A franchise is a type of business. As part of such a business organization, the franchise owner transfers the right to use the brand and technology to another organization independent of it. In the development of higher project education within the franchise, the following can be transferred: the methodology of project education; methods of project selection; methods of evaluating projects and students; methods of teacher training, and more. The franchise organizer can provide information support to those universities that want to work under its franchise. The ranking of project universities is also an information technology. The creation of franchises and ratings of project universities is based on the collection, processing and dissemination of information using modern electronic systems. The use of the franchise and the rating will accelerate the development of the project-based higher education segment.

In the process of system analysis of project-based higher education, the following is established. The project method in higher project education is characterized by the regular implementation of educational projects by students. In the educational process, the implementation of educational projects is an independent type of educational activity of the university. Students carry out educational projects under the scientific supervision of university professors. The introduction of the project method is associated with the creation of a project activity center at the university. Such a center provides: the formation of a list of projects; distribution of students between projects; appointment of research supervisors of projects; planning of the educational process in terms of project work of students; development of a methodology for evaluating projects; development of a methodology for evaluating the work of students by a research supervisor; monitoring the implementation of educational projects. At the same time, educational projects are considered as an independent category and type of educational activities at the university.

The advantages of project-based higher education can be considered as:

- Use of project topics to adapt the university's work to the needs of the economy and society during the transition to a new technological order.

- Systematic integration and integrated practical application of knowledge and skills by students during the implementation of educational projects.

- Timely and more complete integration of education, science and practice in the content of projects and in the course of project implementation.

- Real practical additional professional orientation of students in the process of project implementation.

- Increased motivation of students in the process of their work on educational projects, etc.

The effect of adapting the university to the requirements of the economy is ensured by the fact that educational projects are aimed at solving actual practical problems of the economy.

Risks in the practical use of the project method of higher education can be: difficulties in organizing strategic partnerships with key organizations of clusters and technology platforms; errors in compiling a list of educational projects; problems in creating and working with project groups; the need for professional development of teachers; insufficient methodological support for the process of implementing educational projects, and others.

In the education system, the implementation of programs for the development of higher project education should be managed. The management combines all activities related to: resource allocation; organization of the movement of resources; control of the use of resources. A management system is a set of elements that provide a solution to problems in the development of project education [6].

The program for the development of higher project education includes groups of activities aimed at the development of such components of this type of education:

- Development of the methodology of project activities of real economy organizations.

- Development of strategic partnership between the university and the basic organizations of the real economy.

- Development of the methodology of project-based higher education. 
- Development of pedagogy of project-based higher education.

- Development of the organizational structure of project-based educational activities at the university.

- Development of the organizational culture of higher project education.

The program for the development of higher project education may include a strategy and tactics for such development.

The tools for implementing the program for the development of higher project education can be divided into two categories. Functional tools for implementing development programs include: strategic plans; tactical development plans; organization, motivation, and control over the implementation of project-based higher education development programs.

Operational tools for implementing the program for the development of project-based higher education include: strategic partnership agreements between the university and the enterprise; contracts for targeted training of students; contracts for the performance of research works (R \& D); forward contracts for the training of students with a pre-defined set of competencies; research and educational warrants; rating of project universities, and more.

The topics of educational projects at the university can be offered by enterprises of the real economy. To do this, they must conclude a strategic partnership agreement with the university.

To improve the university's relations with enterprises, it is proposed to create scientific warrants. In the securities market, warrants are used to establish strategic links between the issuer of this security and its buyer. Under the scientific warrant, it is proposed to understand a derivative security. Such a warrant will be issued by a university offering long-term cooperation to organizations of the real economy. The buyers of such warrants will be enterprises of the real economy. Enterprises are interested in long-term cooperation with the university to ensure their own technological competitiveness. The university grants the buyer of such a warrant the right to receive periodic scientific reports of this university. The topics of the reports are determined by the buyer of the warrant. Such reports may include a review of university faculty publications on scientific and technological topics of interest to the buyer of the warrant.

Ratings can become an effective tool for managing the implementation of programs for the development of higher project education. These should be ratings of project universities. At the same time, it should be taken into account that ratings are widely used for university management $[9,10]$. Therefore, it is proposed to develop a separate rating-the rating of project universities $[13,14]$.
The governing effect of ratings is as follows. Economic entities use the results of university ratings to make such decisions. Employers of students (business) use ratings to indirectly assess the value and competence of the workforce they hire to work in their organization. University applicants (clients) use the rating data to select a university based on the "price/quality" criterion of higher education. The Ministry of Higher Education uses the ratings to: evaluate the effectiveness of budget expenditures on education; strategic management of the education system. University administrations actively use ratings in the strategic and tactical management of universities. Professorships take university rankings into account when choosing their employers. Students use the university's ranking to determine the value of their workforce after graduation.

At the beginning of the 21st century, new university rankings are appearing: QS, THE, and others. The wellknown British consulting agency Quacquarelli Symonds (QS) forms an annual international rating of higher education institutions. These are universities from all over the world. The ranking includes 916 universities. In addition to the integral global university rankings, the QS Agency also develops subject-specific university rankings.

The QS agency does not make a rating of project universities. Therefore, it is proposed to make a rating of project universities.

When compiling and using the rating of project universities, it is recommended to take into account the following. It should be taken into account that subject and project higher education form different educational products. In the case of subject education, the product of such education is the sum of knowledge in the subjects studied. In project-based education, the educational product is the student's ability to comprehensively solve a specific problem of a real economy enterprise.

At the beginning of the 21 st century, research shows fundamental differences in the process and project models of organizations ' activities $[12,15,16]$. The process model of organizations was proposed by Henri Fayol in the 1920s. This model provides for the division of all processes in the organization into three parts: main processes; supporting processes; auxiliary processes. This model describes the activities of an organization well in the absence of innovation.

The process model of the organization's activities is presented in Appendix No. 1 (Table No. 1).

For organizations active in the field of innovation, the project model is better suited. Within this model, organizations are represented as a set of projects implemented by this organization. At the same time, the organization is considered as a "portfolio" of its projects.

The project model of the organization's functioning is described in Appendix No. 2 (Table No. 2). 
Glushchenko: Development of a franchise and rating in the formation of programs for the development...

TABLE I. PROCESS MODEL (TABLE) OF THE ORGANIZATION'S ACTIVITIES

\begin{tabular}{|c|c|c|c|c|}
\hline $\begin{array}{l}\text { № } \\
\Pi / \Pi\end{array}$ & $\begin{array}{l}\text { Indicators } \\
\text { Processes in the } \\
\text { organization } \\
/ \text { Names of } \\
\text { processes in the } \\
\text { organization }\end{array}$ & $\begin{array}{c}\text { Costs by type of process } \\
\text { (million rubles) }\end{array}$ & $\begin{array}{l}\text { Revenue by type of process } \\
\text { (million rubles) }\end{array}$ & $\begin{array}{c}\text { Profit/loss by type of } \\
\text { process } \\
\text { (million rubles) }\end{array}$ \\
\hline (1) & (2) & (3) & (4) & (5) \\
\hline 1 & $\begin{array}{c}\text { Basic production } \\
\text { processes }\end{array}$ & 12569 & 25762 & 13193 \\
\hline 2 & $\begin{array}{l}\text { Service production } \\
\text { processes }\end{array}$ & 693 & 1021 & 328 \\
\hline 3 & $\begin{array}{c}\text { Auxiliary } \\
\text { production processes }\end{array}$ & 159 & 58 & -101 \\
\hline 4 & Total result: & 13421 & 26841 & 13420 \\
\hline
\end{tabular}

Source: developed by the author.

TABLE II. PROJECT MODEL (TABLE) OF THE ORGANIZATION'S ACTIVITIES

\begin{tabular}{|c|c|c|c|c|c|c|c|c|}
\hline $\begin{array}{l}\text { № } \\
\Pi / \Pi\end{array}$ & $\begin{array}{c}\text { Performance indicators of } \\
\text { the organization's projects } \\
\text { /Names } \\
\text { organization's projects }\end{array}$ & $\begin{array}{l}\text { Project } \\
\text { start year }\end{array}$ & $\begin{array}{l}\text { Project } \\
\text { completion } \\
\text { year }\end{array}$ & $\begin{array}{l}\text { Project cost } \\
\text { (million } \\
\text { rubles) }\end{array}$ & $\begin{array}{c}\text { Current } \\
\text { investment } \\
\text { volume } \\
\text { (million } \\
\text { rubles) } \\
\end{array}$ & $\begin{array}{l}\text { Project } \\
\text { payback } \\
\text { period }\end{array}$ & $\begin{array}{l}\text { Project } \\
\text { revenue } \\
\text { (million } \\
\text { rubles) }\end{array}$ & $\begin{array}{l}\text { NPV } \\
\text { of the } \\
\text { project }\end{array}$ \\
\hline$(1)$ & (2) & (3) & (4) & $(5)$ & (6) & (7) & (8) & (9) \\
\hline 1 & $\begin{array}{l}\text { Modernization of the } \\
\text { company's products }\end{array}$ & 2021 & 2025 & 115 & 5 & 5 & 0 & 0 \\
\hline 2 & $\begin{array}{c}\text { Modernization of the } \\
\text { company's production } \\
\text { processes }\end{array}$ & 2021 & 2021 & 125 & 10 & 6 & 0 & 0 \\
\hline 3 & $\begin{array}{l}\text { Ensuring the existing } \\
\text { production processes of } \\
\text { the enterprise }\end{array}$ & 2010 & - & 300 & 300 & $\begin{array}{c}\text { Проект } \\
\text { окупился }\end{array}$ & 200 & - \\
\hline
\end{tabular}

Source: developed by the author.

It is predicted that the project model of activity will become the main one for innovatively active enterprises of the sixth technological order. The main methodological and organizational form of innovation is innovation projects. This increases the importance of the project activities of organizations. Therefore, the need for the development of the paradigm of higher project education increases [17]. All this gives grounds to consider the project model of higher education as an independent innovative direction of the development of the higher education system.

In accordance with the geographical location of the university-the subject of such a rating, we can talk about the synthesis of two variants of the rating: the international (global) rating of project universities; the national rating of project universities. Each of these ratings can be considered as an official conclusion (conclusion) of the rating agency on: the results of the project educational activities of the university; the quality of education in the universities participating in the rating.

When synthesizing the rating of project universities, it is recommended to take into account that the basis of this rating is a generalized characteristic of the university's work. Such an assessment is created by summing up the assessments of individual indicators of the university's performance. At the same time, different "weight" coefficients can be assigned to individual indicators of the university's work. In the process of such calculations, they are aggregated (systemically combined) the generalized criterion (a single indicator) includes all relevant information about the work of the university. Such information is concentrated in the specific characteristics (indicators) of the functioning of the project university.

The main objectives of the proposed rating are: to obtain an independent, accurate and reliable assessment of the quality of educational processes; to assess the quality of education at the university; to establish the status of the university in the sequence of similar universities; to identify problems in the scientific and educational activities of the university. At the same time, based on the analysis of trends in changes in university indicators, it is possible to determine trends in the development of the segment of project universities in the national higher education system. 
An important role in the process of creating and using the rating of design universities is played by the mission and vision of the development of the rating of design universities.

The rating of project universities has as its mission the timely adaptation of the higher education system to the development of the project approach in the real economy. The trend of transition to the project model of organizations ' activity will increase in connection with the formation of the sixth technological order. At the same time, it is possible to use the rating to achieve the goals and objectives of the process of strategic management of the higher education system. At the same time, the rating provides objective information to economic and social actors about the quality level and trends in the further development of the project-based higher education segment.

The vision of the rating of project universities can be considered as an inspiring scenario for the development of the project higher education sector in the global and national systems of higher professional education.

The vision of the synthesis of the rating of project universities is as follows. The formation and publication of the rating of project universities will be a significant informational occasion. The discussion of this rating will cause: further popularization of the project approach in higher education; acceleration of the development of the higher project education sector; improvement of the quality of higher project education. The analysis of the rating characteristics and trends in their changes will contribute to the further dynamic expansion of the project-based higher education sector.

At the same time, the key purpose of calculating the rating of project universities can be recognized as the receipt by higher education subjects of information about the state of affairs at the university. The information provided by the rating is: generalized information; structured information; versatile information; independent information, and therefore reliable information about the quality of higher project education at the university. In the field of project-based higher education, the subjects of the process of compiling this rating can be: state, regional, and industry management bodies in the field of education; Public business organizations; individual business representatives (employers); university applicants and students; relatives of applicants and students (who pay for educational services); university administrations, university teaching staff, and others. The rating of project universities can be considered as an indirect characteristic (indicator) of the probability of providing high-quality educational services by this university.

The rating can be considered as a scientific category. In this case, the functions and roles of the rating of project universities should be defined. The functions of the rating as a tool for managing universities in project-based higher education include the following functions:
- Determining the status of a project university among similar universities.

- Quantitative assessment of the quality of research and higher education at the university.

- A university management tool for managing the development of project-based higher education at the university.

- Diagnostic function of the rating of project universities.

- Predictive function of the rating of project universities.

- University ranking optimization function.

- Motivating function of university rankings.

- Control function of the rating of project universities.

- The function of structuring the characteristics of the processes and the quality of the results of project higher education in the university.

- The function of forming evaluation scales for various indicators of the university's activities.

- The function of determining the significance of various processes for the formation of the final rating assessment of the university, and others.

The university status is determined on the basis of a generalized assessment of: the level of scientific research; the quality of educational processes; the level of quality of project higher education in a particular project university. The assessment of the quality of higher education is carried out on the basis of calculations using expert assessments of such indicators: the importance of scientific research; the level of quality of education at the university; characteristics of the degree of perfection of the organization of the process of project higher education at the university. The diagnostic function of the rating of project universities is to use the ratings of this rating to conduct procedures for determining the reasons: the observed scientific results; the status of the university in the field of quality of higher education; the observed assessments of the quality of the educational process at this university. The predictive function of this rating is the ability to use the rating (and the university performance indicators included in it) to predict trends in the development of the higher project education segment and individual universities. The optimization function of the university rating is that such a rating allows you to identify the best practices in the organization of the educational process at the university. The motivating function of the rating of project universities is reflected in the fact that the results of the rating assessment of the university's work create an interest among university administrations to improve the quality of higher project education. The control function of the rating is to confirm in the process of rating evaluation that the university: improves its position; 
retains its position; it worsens its competitive position among similar universities. The function of structuring the characteristics of the processes and the quality of the results of project higher education in the university. follows:

The roles of the rating of project universities can be as

- Determination of the competitive advantages and disadvantages of individual universities and the entire segment of project-based higher education.

- Positioning (determining the position) of this university in the market of educational project services.

- Increasing the effectiveness of the quality management processes of project-based higher education.

- Timely identification of problems in the work of a particular university and / or the entire segment of higher project education, etc.

The formation of an international rating of project universities can be considered as one of the objectives of the program for the development of such higher education.

The sequence of stages of creating a rating of project universities may include the following stages:

- Description of the rating idea, definition of the mission, vision, goals and objectives of creating a rating of project universities.

- Development of a work program for creating a rating of project universities.

- Creation of a rating agency to develop such a rating.

- Formation of the methodology for calculating the rating of project universities.

- Determining the factors that are included in the university assessment questionnaire.

- Determination of "weight" coefficients for each of their characteristics of the project university activity.

- Creating a questionnaire for evaluating the activities of the project university.

- $\quad$ Forming a list of project universities participating in the rating assessment, which will be included in this rating.

- Determining the list of experts who participate in the survey for rating evaluation.

- Survey of experts using questionnaires.

- Collection, processing, registration of the results of the survey of experts.
- Calculation of integrated performance indicators of individual project universities.

- Formation of the rating of project universities as a single list of universities arranged in descending order of the quality of higher education in the universities participating in the rating.

- Analysis of the rating assessment of project universities.

- Publication, publication of the rating of project universities in the press or by other means.

- Announcement of the rating of project universities.

- Explanation of the results of the university rating assessment.

- Development of recommendations on the use of information obtained in the process of compiling the rating of project universities.

Bibliometric analysis can be used to identify the rating factors as structural elements of the rating of project universities. To determine the factors by which it is proposed to evaluate the work of project universities, an analysis of publications on the topic of project higher education was conducted. Data on such publications can be obtained in various scientometric databases.

As a result of the bibliometric analysis:

1) Based on the analysis of the titles of scientific articles, it is possible to determine the list of the most important factors for the quality of higher project education. These factors were included in the rating structure;

2) By identifying the employers of the authors of the articles, it was possible to determine the list of project universities participating in the rating;

3) On the basis of the list of authors of scientific articles, a list of experts can be compiled for conducting an expert rating assessment of project universities.

In the set of indicators (factors) for rating assessment, it is proposed to include the following:

- assessment by an expert of the university's contribution to the development of the methodology of project activities in organizations of the real economy (the indicator is measured in the range from 0 to 10 );

- expert assessment of the university's contribution to the development of the methodology of projectbased higher education (the indicator is measured in the range from 0 to 10 );

- assessment of the university's contribution to the popularization of project-based higher education 
(the indicator is measured in the range from 0 to $10)$;

- employers ' opinion on the level of higher education in the project university (this indicator can be in the range from 0 to 10 );

- the opinion of the scientific and pedagogical community on the issue of assessing the level of scientific work in a certain project university (this indicator is determined in the range from 0 to 10 );

- description of the project method on the website of this university (the characteristic is estimated in the range from 0 to 10 );

- the number of organizations that are strategic partners of this university (the number of partner organizations is multiplied by a weight factor of $0.1)$;

- part (share) of educational projects carried out by joint project groups that include employees of enterprises and university students (the characteristic is in the range from 0 to 1 and is then multiplied by 10 when forming the rating);

- the share of complex educational projects in the total number of projects of this university (this characteristic is estimated in the range from 0 to 1 and then multiplied by a "weight" factor of 10);

- the share of open (with an unknown result in advance) projects at the university (this characteristic is estimated in the range from 0 to 1 and is multiplied by a multiplier of 10 when compiling the rating);

- the presence in the organizational structure of the project university of a structural unit (center of project activities) engaged in the organizational support of the selection, selection and implementation of educational projects at the university (this characteristic is in the range of values from 0 to 10 );

- the presence in the organizational structure of the project university of the department responsible for the development of the scientific and methodological base of the educational project activities of the university (this value is estimated in the range from 0 to 10 );

- the number of scientific publications on the subject of project activities of organizations and project higher education for the entire period of application of this method in the university (for the international (global) rating is taken according to the profile of the university in the GOOGLE Academy; after that, this number of publications is multiplied by a multiplier equal to 0.1 ) and others.

The list of characteristics (and / or their weight coefficients) by which the rating of the project university is determined may change depending on the strategic and/or tactical objectives of the development of the project university.

The resulting rating score of the university is calculated as the sum of all the characteristics presented above, multiplied by their individual "weight" coefficients. In the process of announcing the received ratings, the result is submitted for discussion by the public.

\section{Discussion}

The results of the rating assessment can be used to solve the problems of strategic and tactical management of the development of higher project education. The publication of the rating of project universities should be accompanied by explanations of the circumstances that determine the level of the received assessments of the university's performance.

The publication of the rating should be accompanied by the results of its analytical research. Comments on the rating should include recommendations on the following areas: the reasons for the received ratings; elimination of the reasons that hinder the improvement of the quality of higher project education; measures aimed at increasing the quality of higher project education in individual universities (or their industry groups), the country and at the global level.

The authors of the rating should explain the results obtained by them. The authors of the rating should: interpret the results obtained; develop recommendations for the use of the information obtained; propose measures aimed at overcoming the main problems in the development of higher project education. Such recommendations can be made taking into account the specifics of the development of project education: for individual clusters (regions); for economic sectors; and for the national economy as a whole. At the same time, private ratings of the development of higher project education can be formed by industry, cluster, and region.

The list of measures to develop the methodology and practice of higher project education can include:

- Development of the theoretical foundations of the study of elements and properties of the sixth technological order $[7,16]$;

- Forecasting the features of university activities in the conditions of the sixth technological order [18];

- Development of the paradigm of higher project education [17];

- Formation of a state policy to encourage universities to use the project model of higher education.

- Synthesis of university policy in the development of its own model of higher project education [15]; 
- Development of public-private partnership policy and practice in the process of improving projectbased higher education.

- Generation of legislative proposals that contribute to the development of legal support for higher project education.

- Socialization of knowledge about the advantages of using the project model of organizations in the innovation economy [15].

- Creation of a system of professional development of the teaching staff of project universities [19].

In the interests of organizational support for the development of project-based higher education, the following is recommended:

- Create international and national associations of project universities.

- To create an educational and methodological association (ume) of project universities for the further development of the methodology of higher project education.

- Establish a rating agency that provides a rating of project universities.

- To hold an international scientific and practical conference on the methodology and practice of project activities of organizations.

- To hold a scientific conference on project education.

- To establish an international scientific journal for the publication of articles in the field of the project method in the real economy and higher education.

- Create departments of the theory of project-based higher education.

- Organize annual competitions of educational projects.

- Develop venture (risk) financing of educational and innovative projects and their practical implementation, etc.

The implementation of the program for the development of higher project education in the state can create a strategic competitive advantage, accelerate the development of the country's economy.

\section{Conclusion}

This article substantiates the need to create a program for the development of higher project education, presents a project model of organizations ' activities; shows the reasons why the project approach is becoming more popular in the real economy; describes the advantages and risks of higher project education. The paper describes the structural elements of the program for the development of higher project education. It is proved that the rating of project universities can be an important event in the development program of project universities. The functions and roles of the rating of project universities are described. An algorithm for the compilation and practical use of the rating of project universities is proposed. The structure and components of the rating of project universities are determined. It is proved that the development of projectbased higher education can create competitive advantages and accelerate the socio-economic development of the country.

\section{REFERENCES}

[1] A. Babaev, Why is the franchise so popular and in demand. International Journal of Applied Sciences and Technologies Integral. 2018. no. 2. p. 2.

[2] Project training: implementation practices in universities / Ed. Evstratova L. A., Isaeva N. V., Leshukova O. V. / Open University of Skolkovo, 2018 - - 165 p.

[3] G.Korkmaz, N. Kalayci Theoretical Foundations of Project Based Curriculum in Higher Education / / Çukurova Üiversitesi Eğitim Fakültesi Dergisi. 2019. Vol. 48. no. 1. Pp. 236-274. DOI: 10.14812/cufej. 479322.

[4] M. D. Zavalneva, Innovative potential of project technology in the higher education system//In the collection: Innovative approaches to solving the problems of modern society. collection of articles of the International Scientific and Practical Conference. In 2 parts. Executive editor Gulyaev German Yurievich. 2018. pp. 249-251.

[5] D. A. Khusnullina, Project model of educational programs of higher education//In the book: Youth of the XXI century: education, science, innovation. materials of the VIII All-Russian Student Scientific and Practical conference with international participation. 2019. p. 132-134.

[6] V. V. Glushchenko, I. I. Glushchenko, Research of management systems: sociological, economic, forecast, planned, experimental studies - - Zheleznodorozhny, Moscow region, LLC SPC "Krylia", 2000. $-416 \mathrm{p}$

[7] V. V. Glushchenko, Nauchnaya teoriya tekhnologicheskikh ukladov $\mathrm{i}$ issledovanie napravleniy ee prakticheskogo primeneniya [Scientific theory of technological structures and research of directions of its practical application]. 2020. Vol. 6. No. 4. pp. 488504. https://doi.org/10.33619/2414-2948/53/59

[8] I. B.Trostyanskaya, N. A. Polikhina , Promotion of Russian universities in the leading world rankings: necessary conditions and threshold values for consideration in ratings/ / SOTIS-social technologies, research. 2018. No. 4 (90). pp. 7-27.

[9] V. V. Malishko, L. M. Yaremenko World rankings of universities in the global market of educational services//Economic Bulletin of the University. 2016. No. 31-1. p. 7-15.

[10] V. V. Poluboyarov, Ratings of university sites as a tool for external assessment of the position of an educational organization in the formation of a management strategy//Scientific Bulletin of the Belgorod State University. Series: Economics. Computer science. 2014. No. 15 (186). pp. 58-65.

[11] V. V. Glushchenko, Project model of higher engineering education/ / Kazakhstan Science Journal. 2020. Vol. 3. No. 9 (22). pp. 25-37., https://sciencejournal.press/sj/article/view/210/175 . (accessed 28.09.2020).

[12] V. V. Glushchenko, General theory of project activity of organizations/ / Kazakhstan Science Journal. 2020. Vol. 3. No. 10 (23). pp. 63-75.

[13] V. V. Glushchenko, Rating of project universities and their development strategy // Modern scientific research and innovation. 
2020. No. 11, p. 33. [Electronic resource]. URL: https://web.snauka.ru/issues/2020/11/93817).

[14] V. V. Glushchenko, Strategy and rating in the management system for the development of project-based higher education/ / Kazakhstan Science Journal. 2020. Vol. 3. No. 11 (24). pp. 39-54. https://sciencejournal.press/sj/article/view/225/187. (accessed 16.11.2020).

[15] V. V. Glushchenko, Project model of functioning of the organizations// The scientific heritage, 2020, vol. 3, No. 53 (2020), pp. $15-33$.

[16] V. V. Glushchenko, Scientific theory of the service sector (servicology, service business) in the conditions of the sixth technological order. - M.: Glushchenko Valery Vladimirovich, 2021. - $116 \mathrm{p}$

[17] V. V. Glushchenko, Paradigm of development of higher projectoriented education // Danish scientific journal, No. 41, 2020, vol. 3 , p. 7-15.

[18] V. V. Glushchenko, Theory of technological orders: conceptual transformations in the work of universities in the period of the sixth technological structure//Norwegian Journal of Development of the International Science. 2020. no. 40-3. pp. 5-15.

[19] V. V. Glushchenko, Program of additional professional education in the direction of "venture investor (business angel)" / / Kazakhstan Science Journal. 2020. Vol. 3. No. 10 (2). pp. 38-51, https://sciencejournal.press/sj/article/view/220/183 (accessed 21.10.2020). 